\title{
Morphological, cellular and molecular changes during postovulatory egg aging in mammals
}

\author{
Shilpa Prasad ${ }^{1}$, Meenakshi Tiwari ${ }^{1}$, Biplob Koch ${ }^{2}$ and Shail K. Chaube ${ }^{1 *}$
}

\begin{abstract}
Postovulatory aging is associated with several morphological, cellular and molecular changes that deteriorate egg quality either by inducing abortive spontaneous egg activation (SEA) or by egg apoptosis. The reduced egg quality results in poor fertilization rate, embryo quality and reproductive outcome. Although postovulatory aging-induced abortive SEA has been reported in several mammalian species, the molecular mechanism(s) underlying this process remains to be elucidated. The postovulatory aging-induced morphological and cellular changes are characterized by partial cortical granules exocytosis, zona pellucida hardening, exit from metaphase-II (M-II)arrest and initiation of extrusion of second polar body in aged eggs. The molecular changes include reduction of adenosine 3',5'- cyclic monophosphate (CAMP) level, increase of reactive oxygen species (ROS) and thereby cytosolic free calcium $\left(\mathrm{Ca}^{2+}\right)$ level. Increased levels of CAMP and/or ROS trigger accumulation of Thr-14/Tyr-15 phosphorylated cyclin-dependent kinase 1 (Cdk1) on one hand and degradation of cyclin B1 through ubiquitin-mediated proteolysis on the other hand to destabilize maturation promoting factor (MPF). The destabilized MPF triggers postovulatory aging-induced abortive SEA and limits various assisted reproductive technologies (ARTs) outcome in several mammalian species. Use of certain drugs that can either increase CAMP or reduce ROS level would prevent postovulatory aging-induced deterioration in egg quality so that more number of good quality eggs can be made available to improve ART outcome in mammals including human.
\end{abstract}

Keywords: Postovulatory aging, Abortive SEA, Signal molecules, MPF, ART, Mammals

\section{Introduction}

In mammals, freshly ovulated eggs are arrested at metaphase-II (M-II) stage of meiotic cell cycle and possess first polar body (PB-I) with normal morphology [1-3]. If fertilization does not occur within the window period soon after ovulation, unfertilized eggs remaining in the oviduct or under in vitro culture conditions, undergo time-dependent deterioration in quality by a process called postovulatory egg aging $[4,5]$. Postovulatory aging induces exit from M-II arrest and initiation of second polar body (PB-II) extrusion [2]. The chromosomes are scattered in the cytoplasm and aged eggs are further arrested at metaphase-III (M-III) like stage without forming pronuclei [2]. The initiation of extrusion of PB-II occurs soon after ovulation and large amount of cytoplasm move towards PB-II area but it never gets

\footnotetext{
* Correspondence: shailchaubey@gmail.com

${ }^{1}$ Cell Physiology Laboratory, Biochemistry Unit, Department of Zoology,

Banaras Hindu University, Varanasi 221005, UP, India

Full list of author information is available at the end of the article
}

completely extruded. This atypical condition is called spontaneous egg activation (SEA) [2].

The SEA was reported in rat for the first time by Keefer and Schuetz in 1982 [6] and later by several research groups [2, 5, 7-11]. This pathological condition has also been observed in several mammalian species such as mice $[12,13]$, porcine [14-16], bovine [17], hamster [18] and human eggs [19-21]. The percentage of eggs undergoing SEA varies from species to species in mammals. Ross et al. (2006) observed that approximately $35 \%$ to $85 \%$ of ovulated eggs undergo SEA in different strains of rat. Studies from our laboratory suggest that the postovulatory egg aging results SEA in $90 \%$ of ovulated eggs in vivo as well as in vitro $[2,3,8,9]$. In human, egg aging is one of the problems associated with ART failure [4]. Therefore, improvements of egg quality through methodological advances are in critical demand to prevent egg aging process during ART procedure [4]. Aged eggs limits the ART outcome, hence the establishment of method(s) to

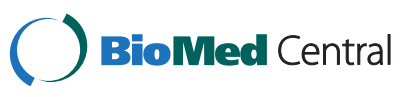

(c) 2015 Prasad et al. This is an Open Access article distributed under the terms of the Creative Commons Attribution License (http://creativecommons.org/licenses/by/4.0), which permits unrestricted use, distribution, and reproduction in any medium provided the original work is properly credited. The Creative Commons Public Domain Dedication waiver (http:// creativecommons.org/publicdomain/zero/1.0/) applies to the data made available in this article, unless otherwise stated. 
prevent egg aging could enhance progress in ART technologies and their outcome [4]. Based on our recent findings, we propose that the postovulatory aging-induced abortive SEA could be due to changes in the level of signal molecules and their effect on maturation promoting factor (MPF) because the high level of MPF heterodimer and cytostatic factors (CSF) activity are required for maintenance of M-II arrest in freshly ovulated eggs [22, 23]. The postovulatory aging reduces egg quality by inducing apoptosis that finally affect reproductive outcome [2, 3, 24-29].

\section{Review}

\section{Morphological changes during postovulatory egg aging}

Normally egg activation is triggered by fertilizing spermatozoa and it is morphologically characterized by cortical granule exocytosis, pronuclei formation and complete extrusion of PB-II in mammal [2, 12, 30]. In the absence of fertilization, in several mammalian species, postovulatory aging induces SEA both in vivo as well as in vitro, which mimics the morphological features characteristics of egg activation $[2,6,7,19,31,32]$. In rat, postovulatory aging induces incomplete extrusion of PB-II without forming pronuclei and eggs are arrested at M-III like stage so called abortive SEA (Fig. 1) [2]. The large amount of egg cytoplasm moves towards PB-II and it is not cytoplasmic division, which results partial extrusion of PB-II. The incomplete extrusion of PB-II generates a pathological condition because these eggs cannot be used for assisted reproductive technology (ART) program [2]. The postovulatory aging triggers degeneration of PB-I, increases perivitelline space (PVS) and partial cortical granule exocytosis [4]. Due to energy depletion, postovulatory aging generates ROS and thereby egg apoptosis [28, 33]. The egg apoptosis has been morphologically characterized by

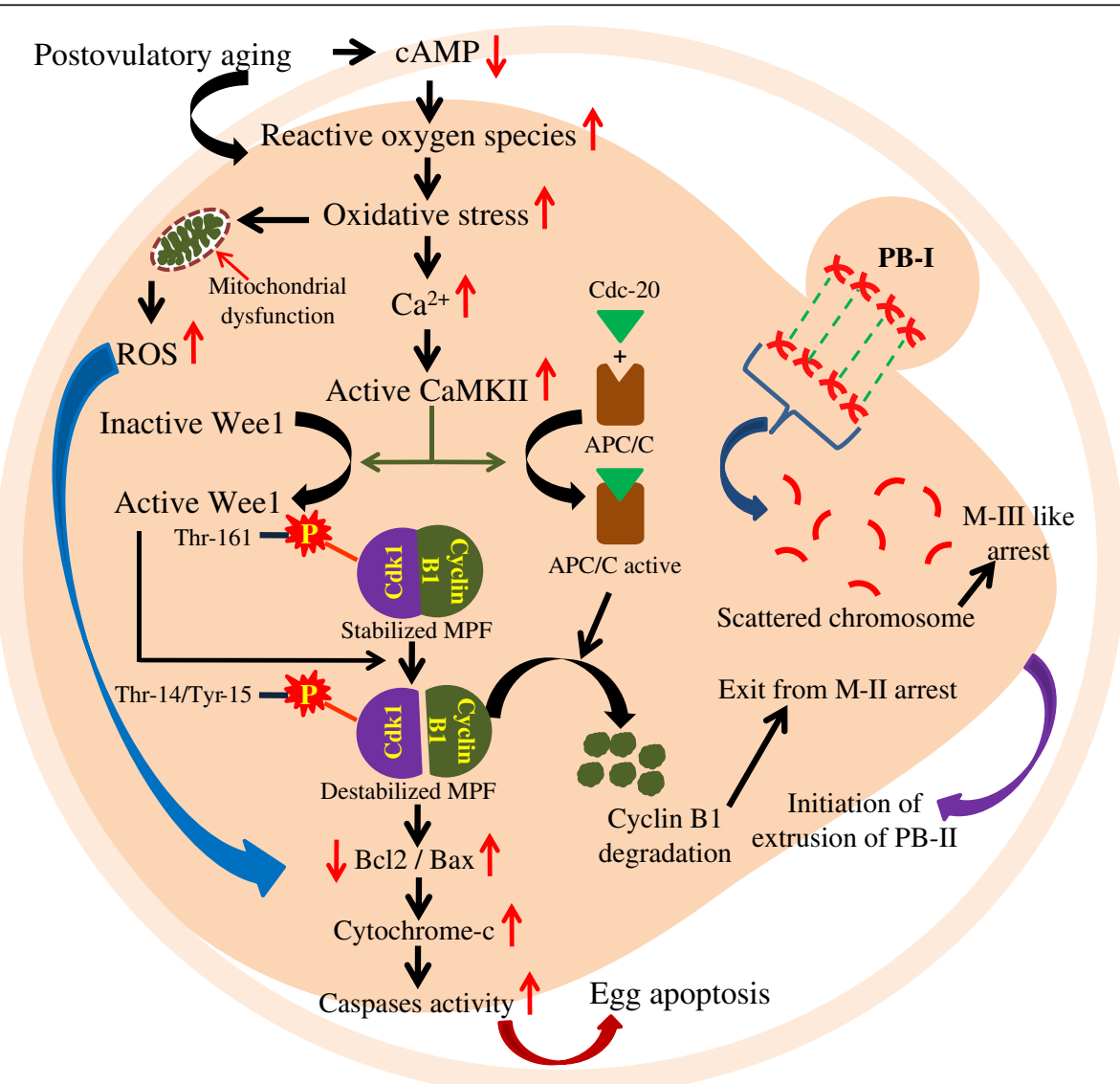

Fig. 1 A schematic diagram showing the molecular changes associated with postovulatory aging-induced abortive SEA. Postovulatory egg aging reduces CAMP and/or induces generation of ROS that results in oxidative stress. The oxidative stress impairs mitochondrial membrane potential and increases cytosolic free $\mathrm{Ca}^{2+}$ level. The increased cytosolic free $\mathrm{Ca}^{2+}$ level results in the activation of Wee1 and APC/C. Wee1 modulates Cdk1 phosphorylation and destabilizes MPF heterodimer. The active APC/C triggers cyclin B1 degradation through ubiquitin-mediated proteolysis. The destabilized MPF triggers an exit from M-II arrest but chromosomes are scattered in the cytoplasm and pronuclei is not formed. The increased level of ROS and/or sustained destabilized MPF may trigger proapoptotic as well as apoptotic factors leading to apoptosis in aged eggs. Increased CAMP level and decreased $\mathrm{Ca}^{2+}$ and ROS levels using specific drugs could be beneficial to prevent postovulatory aging-induced deterioration of egg quality 
shrinkage, membrane blebbing, cytoplasmic fragmentation, cytoplasmic granulation and degeneration $[1,9-11$, $28,33-38]$.

\section{Cellular changes during postovulatory egg aging}

Postovulatory aging causes tight aggregations of granulofibrillar material and zona pellucida hardening in eggs $[4,12,39,40]$. Thick microfilament domain underlying the plasma membrane is either disrupted or lost [41]. Number of lysosomes is increased and tubuli from smooth endoplasmic reticulum and small mitochondriacomplexes are aggregated in aged eggs $[4,42]$. Cortical granules are displaced and undergo partial exocytosis $[4,12,39,40]$. The mitochondria membrane potential is decreased, which results in the swelling of matrix [43]. Length of spindle is reduced leading to severe consequences for chromosome segregation. The centrosome structure, microtubule integrity and maintenance of chromosome at metaphase plate are lost $[4,44,45]$. As a result, pronuclei is not formed during postovulatory aging-induced abortive SEA (Fig. 1). Further, postovulatory aging triggers premature chromosome separation, chromosomal dispersion and decondensation, clumping of chromosome and chromatid separation in eggs $[4,46,47]$ that could lead to epigenetic changes in offspring $[23,48]$.

\section{Molecular changes during postovulatory egg aging}

The depletion of ATP reserve and thereby adenosine 3',5'- cyclic monophosphate (cAMP) that leads to generation of reactive oxygen species (ROS) in aged eggs $[33,37,38]$. The decrease of intracellular cAMP in aging eggs is one of the important signals that initiates an exit from M-II arrest [2, 49]. Few studies suggest that reduced cAMP level is associated with an increase of hydrogen peroxide $\left(\mathrm{H}_{2} \mathrm{O}_{2}\right)$ in aged eggs cultured in vitro $[50,51]$. The lack of antioxidants and increased oxygen tension are other important factors that triggers the generation of ROS [13, 23, 52, 53].

Increased oxidative stress due to generation of ROS causes dysfunction and shrinkage of mitochondria $[23,38]$ that reduces mitochondrial membrane potential in aging eggs [53,54]. This is further supported by our observations that exogenous supplementation of dibutyryl cAMP (db-cAMP) or non-enzymatic antioxidant prevents postovulatory aging-induced abortive SEA [1-3]. Oxidative stress induces expression of proapoptotic factors (Bax and cytochrome c) and apoptotic factors (caspase-3 and DNA fragmentation) and thereby apoptosis in aged eggs cultured in vitro $[9,55]$. The increased level of $\mathrm{H}_{2} \mathrm{O}_{2}$ reduces Bcl2 expression [56], increases Bax expression [9, 34, 38], cytochrome c level, caspases activities $[28,33,38,55]$ and DNA fragmentation in rat eggs cultured in vitro [9].
Postovulatory aging-induced oxidative stress can modulate RyR channels of endoplasmic reticulum and increase cytosolic free calcium $\mathrm{Ca}^{2+}$ level [3]. This is further strengthened by our recent studies that ruthenium red, a specific RyR channel blocker reduces cytosolic free $\mathrm{Ca}^{2+}$ level and inhibits postovulatory aging-induced abortive SEA [3]. Further, increased $\mathrm{H}_{2} \mathrm{O}_{2}$ level associates with high cytosolic free $\mathrm{Ca}^{2+}$ level during postovulatoryinduced abortive SEA [1-3, 10, 36, 38]. The increased intracellular $\mathrm{Ca}^{2+}$ activates CaM-dependent kinase-II (CaMKII) $[3,57,58]$ and KN93, a specific CaMKII inhibitor prevents postovulatory aging-induced abortive SEA $[57,58]$. On the other hand, due to high sustained level of $\mathrm{Ca}^{2+}$ in the cytoplasm, $\mathrm{Ca}^{2+}$ enters in the mitochondria and triggers generation of ROS, mitochondrial DNA damage and apoptosis in aged eggs cultured in vitro (Fig. 1) [2, 38, 59, 60].

The CaMK-II activates anaphase promoting complex/ cyclosome $(\mathrm{APC} / \mathrm{C})$ by releasing endogenous meiotic inhibitor 2 (Emi2; a CSF) as well as Wee 1, a tyrosine kinase [61, 62]. Previous study suggests that increased level of ROS can also stimulate tyrosine kinase [63]. The active Wee 1 destabilizes MPF by inducing phosphorylation of Thr-14/Tyr-15 of Cdk1 (a catalytic unit of MPF) and triggers dissociation of cyclin B1 (a regulatory subunit of MPF) from MPF heterodimer [61, 62, 64]. The active APC/C induces degradation of cyclin B1 through ubiquitin-mediated proteolysis [61]. The destabilized MPF finally triggers an exit from M-II arrest and thereby initiation of extrusion of PB-II in aged eggs [40]. The postovulatory aging-induced MPF destabilization can be prevented using several drugs that can elevate cAMP level or reduce ROS level [2, 23, 65, 66]. Other drugs like demecolcine, nocodazole, cytochalasin (B and $\mathrm{D}$ ) and $\mathrm{Na}^{+} / \mathrm{Ca}^{2+}$ exchanger of plasma membrane prevent postovulatory aging-induced abortive SEA in rat oocytes [67-69]. Although, postovulatory aging induces initiation of extrusion of PB-II but it never gets completely extruded and chromosomes remain scattered in egg cytoplasm without forming pronuclei [2]. The reduced level of destabilized MPF and ATP depletion in aged egg result in increased expression of proapoptotic factors $[26,70,71]$. Overexpression of proapoptotic factors activate upstream as well as downstream caspases [13, 72] that deteriorates egg quality by inducing apoptosis $[26,73-75]$. Indeed, postovulatory aging-induced deterioration of egg quality could be one of the limiting factors for poor in vitro fertilization rate in several mammalian species including human.

\section{Conclusions}

Postovulatory aging-induced abortive SEA is a pathological condition in mammals that limits ART outcome. Generation of ROS results in oxidative stress that 
increases cytosolic free $\mathrm{Ca}^{2+}$ level. Aged eggs are unable to sustained high level of $\mathrm{Ca}^{2+}$, which leads to MPF destabilization. The destabilized MPF triggers exit from M-II arrest, a characteristic feature of abortive SEA (Fig. 1). In aged eggs, chromosomes are scattered in the egg cytoplasm and pronuclei is not formed. The increased oxidative stress and/or destabilized MPF deteriorate egg quality by inducing apoptosis. Although growing body of evidences suggest the possible players and pathways during postovulatory egg aging, further, studies are required to prevent aging process so that the good quality eggs are made available for various ART programs including somatic cell nuclear transfer during animal cloning.

\begin{abstract}
Abbreviations
ART: Assisted reproductive technology; APC/C: Anaphase promoting complex/cyclosome; cAMP: Adenosine 3',5'- cyclic monophosphate; $\mathrm{Ca}^{2}$ ${ }^{+}$: Calcium; CaMKIl: CaM-dependent kinase-ll; Cdk1: Cyclin-dependent kinase 1; CSF: Cytostatic factor; db-CAMP: Dibutyryl cAMP; Emi2: Endogenous meiotic inhibitor 2; $\mathrm{H}_{2} \mathrm{O}_{2}$ : Hydrogen peroxide; M-II: Metaphase-ll; M-III: Metaphase-III; MPF: Maturation promoting factor; PB-I: Polar body-l; PB-II: polar body-ll; PVS: perivitelline space; ROS: reactive oxygen species; SEA: spontaneous egg activation.
\end{abstract}

\section{Competing interests}

The authors declare that they have no competing interests.

\section{Authors' contributions}

SP and MT searched the literature and wrote the initial draft of manuscript. BK and SKC suggested the structure, revised and finished the final version of manuscript. All authors read and approved the final manuscript.

\section{Acknowledgement}

The part of this study was funded by Department of Biotechnology, Ministry of Science and Technology, Government of India.

\section{Author details}

${ }^{1}$ Cell Physiology Laboratory, Biochemistry Unit, Department of Zoology, Banaras Hindu University, Varanasi 221005, UP, India. ${ }^{2}$ Genotoxicology and Cancer Biology Laboratory, Department of Zoology, Banaras Hindu University, Varanasi 221005, UP, India.

\section{Received: 20 February 2015 Accepted: 1 May 2015}

Published online: 22 May 2015

\section{References}

1. Tripathi A, Prem Kumar KV, Chaube SK. Meiotic cell cycle arrest in mammalian oocytes. J Cell Physiol. 2010;223:592-600.

2. Premkumar KV, Chaube SK. An insufficient increase of cytosolic free calcium level results postovulatory aging-induced abortive spontaneous egg activation in rat. J Assist Reprod Genet. 2013;30:117-23.

3. Premkumar KV, Chaube SK. RyR channel-mediated increase of cytosolic free calcium level signals cyclin B1 degradation during abortive spontaneous egg activation in rat. In Vitro Cell Dev Biol-Anim. 2014;50:640-7.

4. Miao YL, Kikuchi K, Sun QY, Schatten H. Oocyte aging: cellular and molecular changes, developmental potential and reversal possibility. Hum Reprod Update. 2009:15:573-85

5. Chebotareva T, Taylor J, Mullins JJ, Wilmut I. Rat eggs cannot wait: spontaneous exit from meiotic metaphase-ll arrest. Mol Reprod Dev. 2011;78:795-807

6. Keefer CL, Schuetz AW. Spontaneous activation of ovulated rat oocytes during in vitro culture. J Exp Zool. 1982;224:371-7.

7. Zernika-Goetz M. Spontaneous and induced activation of rat oocytes. Mol Reprod Dev. 1991;28:169-76.

8. Ross PJ, Yabuuchi A, Cibelli JB. Oocyte spontaneous activation in different rat strains. Cloning Stem Cells. 2006;8:275-82.
9. Chaube SK, Dubey PK, Mishra SK, Shrivastav TG. Verapamil reversibly inhibits spontaneous parthenogenetic activation in aged rat eggs cultured in vitro. Cloning Stem Cells. 2007;9:608-17.

10. Chaube SK, Khatun S, Misra SK, Shrivastav TG. Calcium ionophore-induced egg activation and apoptosis with the generation of intracellular hydrogen peroxide. Free Rad Res. 2007:42:212-20.

11. Tripathi A, Khatun S, Pandey AN, Misra SK, Chaube R, Shrivastava TG, et al. Intracellular levels of hydrogen peroxide and nitric oxide in oocyte at various stages of meiotic cell cycle and apoptosis. Free Rad Res. 2009;43:287-94.

12. Xu Z, Abbott A, Kopf GS, Schultz RM, Ducibella T. Spontaneous activation of ovulated mouse eggs: time-dependent effects on M-phase exit, cortical granule exocytosis, maternal messenger ribonucleic acid recruitment, and Inositol 1,4,5-trisphosphate sensitivity. Biol Reprod. 1997;57:743-50.

13. Lord T, Nixon B, Jones KT, Aitken RJ. Melatonin prevents postovulatory oocyte aging in the mouse and extends the window for optimal fertilization in vitro. Biol Reprod. 2013;88:1-9.

14. Ruddock NT, Machaty Z, Cabot RA, Prather RS. Porcine oocyte activation: roles of calcium and pH. Mol Reprod Dev. 2001;59:227-34.

15. Ito J, Shimada M, Terada T. Effect of protein kinase $\mathrm{C}$ inhibitor on mitogen-activated protein kinase and p34cdc2 kinase activity during parthenogenetic activation of porcine oocytes by calcium ionophore. Biol Reprod. 2003;69:1675-82.

16. Ito J, Shimada M, Terada T. Mitogen-activated protein kinase kinase inhibitor suppresses cyclin B1 synthesis and reactivation of p34cdc2 kinase, which improves pronuclear formation rate in matured porcine oocytes activated by $\mathrm{Ca}^{2+}$ ionophore. Biol Reprod. 2004;70:797-804.

17. Sergeev IN, Norman AV. Calcium as a mediator of apoptosis in bovine oocytes and preimplantation embryos. Endocrine. 2003;22:169-76.

18. Juetten J, Bavister BD. Effects of egg aging on in vitro fertilization and first cleavage division in the hamster. Gamete Res. 1983;8:219-30.

19. Lu Q, Chen ZJ, Gao X, Ma SY, Li M, Hu JM, et al. Oocyte activation with calcium ionophore A23187 and puromycin on human oocytes that failed to fertilize after intracytoplasmic sperm injection. Zhonghua Fu Chan Ke Za Zhi. 2006:41:182-5.

20. Escrich L, Grau N, Mercader A, Rubio C, Pellicer A, Escriba MJ. Spontaneous in vitro maturation and artificial activation of human germinal vesicle oocytes recovered from stimulated cycles. J Assist Reprod Genet. 2011;28:111-7.

21. Combelles CMH, Kearns WG, Fox JH, Racowsky C. Cellular and genetic analysis of oocytes and embryo in a case of spontaneous oocyte activation. Hum Reprod. 2011;26:545-52.

22. Madgwick S, Jones KT. How eggs arrest at metaphase II: MPF stabilization plus APC/C inhibition equals cytostatic factor. Cell Div. 2007;2:4-11.

23. Lord T, Aitken RJ. Oxidative stress and ageing of the post-ovulatory oocyte. Reproduction. 2013;146:R217-27.

24. Wilcox AJ, Weinberg CR, Baird DD. Post-ovulatory ageing of the human oocyte and embryo failure. Hum Reprod. 1998;13:394-7.

25. Tarin JJ, Pérez-Albalá S, Aguilar A, Miñarro J, Hermenegildo C, Cano A. Long-term effects of postovulatory aging of mouse oocytes on offspring: a two-generational study. Biol Reprod. 1999;61:1347-55.

26. Gordo AC, Rodrigues P, Kurokawa M, Jellerette T, Exley GE, Warner C, et al. Intracellular calcium oscillations signal apoptosis rather than activation in in vitro aged mouse eggs. Biol Reprod. 2002;66:1828-37.

27. Steuerwald NM, Steuerwald MD, Mailhes JB. Post-ovulatory aging of mouse oocytes leads to decreased MAD2 transcripts and increased frequencies of premature centromere separation and anaphase. Mol Hum Reprod. 2005:11:623-30.

28. Tripathi A, Chaube SK. Reduction of phosphorylated Thr-161 Cdk1 level participates in roscovitine-induced Fas ligand-mediated apoptosis in rat eggs cultured in vitro. In Vitro Cell Dev Biol-Anim. 2014; doi:10.1007/s11626-014-9812-8.

29. Prasad S, Premkumar KV, Koch B, Chaube SK. Abortive spontaneous egg activation: a pathological condition in mammalian egg. ISSRF News Letter. 2014;14:25-7.

30. Schultz RM, Kopf GS. Molecular basis of mammalian egg activation. Curr Top Dev Biol. 1995;30:21-62.

31. Kubiak JZ. Mouse oocytes gradually develop the capacity for activation during the metaphase II arrest. Dev Biol. 1989;136:537-45.

32. Miyazaki S, Yuzaki M, Nakada K, Shirakawa H, Nakanishi S, Nakade S, et al. Block of $\mathrm{Ca}^{2+}$ wave and $\mathrm{Ca}^{2+}$ oscillation by antibody to the inositol 1,4,5trisphosphate receptor in fertilized hamster eggs. Science. 1992;257:251-5. 
33. Tripathi A, Shrivastav TG, Chaube SK. An increase of granulosa cell apoptosis mediates aqueous neem (Azadirachta indica) leaf extract induced oocyte apoptosis in rat. Int J Appl Basic Med Res. 2013;3:27-36.

34. Chaube SK, Prasad PV, Thakur SC, Shrivastav TG. Hydrogen peroxide modulates meiotic cell cycle and induces morphological features characteristic of apoptosis in rat oocytes cultured in vitro. Apoptosis 2005;10:863-74.

35. Chaube SK, Prasad PV, Khillare B, Shrivastav TG. Extract of Azadirachta indica (Neem) leaf induces apoptosis in rat oocytes cultured in vitro. Fertil Steril. 2006;85:1223-31.

36. Chaube SK, Tripathi A, Khatun S, Misra SK, Prasad PV, Shrivastav TG. Extracellular calcium protects against verapamil-induced metaphase-II arrest and initiation of apoptosis in aged rat eggs. Cell Biol Int. 2009;33:337-43.

37. Chaube SK, Shrivastav TG, Tiwari M, Prasad S, Tripathi A, Pandey AK. Neem (Azadirachta indica L.) leaf extract deteriorates oocyte quality by inducing ROS-mediated apoptosis in mammals. SpringerPlus. 2014;3:464-8.

38. Tripathi A, Chaube SK. High cytosolic free calcium level signals apoptosis through mitochondria-caspase mediated pathway in rat eggs cultured in vitro. Apoptosis. 2012;17:439-48.

39. Goud AP, Goud PT, Diamond MP, Abu-Soud HM. Nitric oxide delays oocyte aging. Biochemistry. 2005:44:11361-8.

40. Miao YL, Liu XY, Qiao TW, Miao DQ, Luo MJ, Tan JH. Cumulus cells accelerate aging of mouse oocytes. Biol Reprod. 2005;73:1025-31.

41. Kim NH, Moon SJ, Prather RS, Day BN. Cytoskeletal alteration in aged porcine oocytes and parthenogenesis. Mol Reprod Dev. 1996;43:513-8.

42. Sundstrom P, Nilsson BO, Liedholm P, Larsson E. Ultrastructural characteristics of human oocytes fixed at follicular puncture or after culture. J In Vitro Fert Embryo Transf. 1985;2:195-206.

43. Wilding M, Dale B, Marino M, di Matteo L, Alviggi C, Pisaturo ML, et al. Mitochondrial aggregation patterns and activity in human oocytes and preimplantation embryos. Hum Reprod. 2001;16:909-17.

44. Sun QY, Schatten $\mathrm{H}$. Centrosome inheritance after fertilization and nuclear transfer in mammals. Adv Exp Med Biol. 2007;591:58-71.

45. Schatten $\mathrm{H}$. The mammalian centrosome and its functional significance. Histochem Cell Biol. 2008;129:667-86.

46. Van Wissen B, Bomsel-Helmreich O, Debey P, Eisenberg C, Vautier D, Pennehouat $\mathrm{G}$. Fertilization and ageing processes in non-divided human oocytes after $\mathrm{GnRH}$ a treatment: an analysis of individual oocytes. Hum Reprod. 1991;6:879-84.

47. Zenzes MT, Casper RF. Cytogenetics of human oocytes, zygotes, and embryos after in vitro fertilization. Hum Genet. 1992;88:367-75.

48. Liang XW, Zhu JQ, Miao Y, Liu J, Wei L, Lu S, et al. Loss of methylation imprint of Snrpn in postovulatory aging, mouse oocyte. Biochem Biophys Res Commun. 2008;371:16-21.

49. Vaccari S, Weeks II J, Hsieh M, Menniti FS, Conti M. Cyclic GMP signaling is involved in the luteinizing hormone-dependent meiotic maturation of mouse oocytes. Biol Reprod. 2009;81:595-604.

50. Cheon YP, Kim SW, Kim SJ, Yeom Y, Cheong C, Ha KS. The role of RhoA in the germinal vesicle breakdown of mouse oocytes. Biochem Biophy Res Commun. 2000;273:997-1002.

51. Pandey A, Chaube SK. A moderate increase of hydrogen peroxide level is beneficial for spontaneous resumption of meiosis from diplotene arrest in rat oocytes cultured in vitro. BioRes Open Access. 2014;3:183-91.

52. Tatone C, Emidio GD, Barbaro R, Vento M, Ciriminna R, Artini PG. Effects of reproductive aging and postovulatory aging on the maintenance of biological competence after oocyte vitrification: insights from the mouse model. Theriogenology. 2011;76:864-73.

53. Zhang N, Wakai T, Fissore RA. Caffeine alleviates the deterioration of Ca (2+) release mechanisms and fragmentation of in vitro-aged mouse eggs. $\mathrm{Mol}$ Reprod Dev. 2011;78:684-701.

54. Liu H, Wang T, Huang K. Cholestane-3B, 5a, 6B-triol-induced reactive oxygen species production promotes mitochondrial dysfunction in isolated mice liver mitochondria. Chem Biol Interact. 2009;179:81-7.

55. Liu L, Trimarchi JR, Keefe DL. Involvement of mitochondria in oxidative stress-induced cell death in mouse zygotes. Biol Reprod. 2000;62:1745-53.

56. Takahashi E, Igarashi H, Kawagoe J, Amita M, Hara S, Kurachi H. Poor embryo development in mouse oocytes aged in vitro is associated with impaired calcium homeostasis. Biol Reprod. 2009;80:493-502.

57. Ito J, Kaneko R, Hirabayashi M. The regulation of calcium/calmodulin-dependent protein kinase II during oocyte activation in the rat. J Reprod Dev. 2006;52:439-47.
58. Yoo JC, Smith LC. Extracellular calcium induces activation of $\mathrm{Ca}^{2}$ ${ }^{+} /$calmodulin dependent protein kinase II and mediates spontaneous activation in rat oocytes. Biochem Biophys Res Commun. 2007;359:854-9.

59. Shigenaga MK, Hagen TM, Ames BN. Oxidative damage and mitochondrial decay in aging. PNAS. 1994;91:10771-8.

60. Tosti E. Calcium ion currents mediating oocyte maturation events. Reprod Biol Endocrinol. 2006;4:26-34.

61. Kubiak JZ, Ciemerych MA, Hupalowska A, Sikora-Polaczek M, Polanski Z. On the transition from the meiotic cell cycle during early mouse development Int J Dev Biol. 2008;52:201-17.

62. Oh JS. Protein tyrosine kinase Wee1B is essential for metaphase II exit in mouse oocytes. Science. 2011;332:462-5.

63. Chan TM, Chen E, Tatoyan A, Shargill NS, Pleta M, Hochstein P. Stimulation of tyrosine-specific protein phophorylation in the rat liver plasma membrane by oxygen radicals. Biochem Biophys Res Commun. 1986;139:439-45.

64. Oh JS, Susor A, Schindler K, Schultz RM, Conti M. Cdc25A activity is required for the metaphase II arrest in mouse oocytes. J Cell Sci. 2013;126:1081-5.

65. Kikuchi K, Naito K, Noguchi J, Kaneko H, Tojo H. Maturation/M-phase promoting factor regulates aging of porcine oocytes matured in vitro. Cloning Stem Cells. 2002;4:211-22.

66. Ono T, Mizutani E, Li C, Yamagata K, Wakayama T. Offspring from intracytoplasmic sperm injection of aged mouse oocytes treated with caffeine or MG132. Genesis. 2011;49:460-71.

67. Zernika-Goetz M, Kubiak JZ, Antony C, Maro B. Cytoskeletal organization of rat oocytes during metaphase II arrest and following abortive activation: a study by confocal laser scanning microscopy. Mol Reprod Dev. 1993;35:165-75.

68. Galat V, Zhou Y, Taborn G, Garton R, lannaccone P. Overcoming M-III arrest from spontaneous activation in cultured rat oocytes. Cloning Stem Cells. 2007;9:303-14

69. Cui W, Zhang J, Zhang CX, Jiao GZ, Zhang M, Wang TY. Control of spontaneous activation of rat oocytes by regulating plasma membrane $\mathrm{Na}$ ${ }^{+} / \mathrm{Ca}^{2+}$ exchanger activities. Biol Reprod. 2013;88:1-9.

70. Fissore RA, Kurokawa M, Knott J, Zhang M, Smyth J. Mechanisms underlying oocyte activation and postovulatory ageing. Reproduction. 2002;124:745-54.

71. Ma W, Zhang D, Hou Y, Li YH, Sun QY, Sun XF, et al. Reduced expression of MAD2, BCL2, and MAP kinase activity in pig oocytes after in vitro aging are associated with defects in sister chromatid segregation during meiosis II and embryo fragmentation after activation. Biol Reprod. 2005;72:373-83.

72. Takai Y, Matikainen T, Juriscova A, Kim MR, Trbovich AM, Fujita E, et al. Caspase-12 compensates for lack of caspase-2 and caspase-3 in female germ cells. Apoptosis. 2007;12:791-800.

73. Hsu SY, Hsueh AJ. Tissue-specific Bcl-2 protein partners in apoptosis: an ovarian paradigm. Physiol Rev. 2000;80:593-614.

74. Tatone C, Carbone MC, Gallo R, Delle Monache S, Di Cola M, Alesse E, et al. Age-associated changes in mouse oocytes during postovulatory in vitro culture: possible role for meiotic kinases and survival factor BCL2. Biol Reprod. 2006;74:395-402.

75. Verbert L, Lee B, Kocks SL, Assefa Z, Parys JB, Missiaen L, et al. Caspase-3truncated type 1 inositol 1, 4, 5-triphosphate receptor enhances intracellular $\mathrm{Ca}^{2+}$ leak and disturbs Ca ${ }^{2+}$ signalling. Biol Cell. 2008;1000:39-49.

\section{Submit your next manuscript to BioMed Central and take full advantage of:}

- Convenient online submission

- Thorough peer review

- No space constraints or color figure charges

- Immediate publication on acceptance

- Inclusion in PubMed, CAS, Scopus and Google Scholar

- Research which is freely available for redistribution 